Abstracta Iranica Abstracta Iranica

Revue bibliographique pour le domaine irano-aryen

Volume 23 | 2002

Comptes rendus des publications de 2000

\title{
"Anciens monuments sur l'eau, selon Tarsusi », Environmental Design. Trails to the East. Essays in Memory of Paolo Cuneo. Roma, 2000, pp. 137-143.
}

\section{Marina Gaillard}

\section{(2) OpenEdition}

1 Journals

\section{Édition électronique}

URL : http://journals.openedition.org/abstractairanica/35819

DOI : 10.4000/abstractairanica.35819

ISSN : 1961-960X

Éditeur :

CNRS (UMR 7528 Mondes iraniens et indiens), Éditions de l'IFRI

\section{Édition imprimée}

Date de publication : 15 mai 2002

ISSN : 0240-8910

Référence électronique

Marina Gaillard, « "Anciens monuments sur l'eau, selon Tarsusi », Environmental Design. Trails to the East. Essays in Memory of Paolo Cuneo. Roma, 2000, pp. 137-143. ", Abstracta Iranica [En ligne], Volume 23 | 2002, document 279, mis en ligne le 08 février 2010, consulté le 25 septembre 2020. URL : http:// journals.openedition.org/abstractairanica/35819; DOI : https://doi.org/10.4000/abstractairanica. 35819

Ce document a été généré automatiquement le 25 septembre 2020.

Tous droits réservés 


\title{
«Anciens monuments sur l'eau, selon Tarsusi », Environmental Design. Trails to the East. Essays in Memory of Paolo Cuneo. Roma, 2000, pp. 137-143.
}

\author{
Marina Gaillard
}

1 Toujours passionné par les aspects techniques du Dārāb-nāme d'Abū Țāher Țarsūsī (12 s., en partie un "roman d'Alexandre » en prose), l'A. s'intéresse à dix constructions architecturales étonnantes bâties sur l'eau, présentées par le récit « à l'instar de visites de sites archéologiques ». Les unes sont l'œuvre des "philosophes techniciens », sans lesquels Alexandre serait impuissant à réaliser quoi que soit (en particulier Loqmān, et "le grand maître » Platon), les autres ont été érigées dans le passé par différents personnages. Les aspects techniques de ces constructions sont analysés de près, la mise en œuvre de ces travaux colossaux étant en effet rapportée avec un luxe de détails surprenant. Mais surtout, l'A. s'attache à l'identification des anthroponymes et toponymes qui abondent dans le texte, "mal représentés en écriture arabe, sinon défigurés par les copistes ». Ces lectures renvoient à la richesse des sources du récit, nombreuses et multiples (en particulier des sources grecques), et permettent d'établir des analogies troublantes avec d'autres récits de traditions différentes. Un texte tout à la fois plaisant et savant.

\section{INDEX}

Thèmes : 11.1.1. Littérature persane classique 
AUTEURS

MARINA GAILLARD

CNRS - Paris 